\title{
TEACHING AND LEARNING ENGLISH LINGUISTICS AT UNDERGRADUATE LEVEL AT THE UNIVERSITY OF LANGUAGES AND INTERNATIONAL STUDIES - VIETNAM NATIONAL UNIVERSITY, HANOI: CHANGES OVER THE LAST TEN YEARS
}

\author{
Nguyen Thi Minh Tam* \\ Faculty of Linguistics and Cultures of English-speaking Countries, VNU University of Languages \\ and International Studies, Pham Van Dong, Cau Giay, Hanoi, Vietnam
}

Received 03 August 2018

Revised 25 September 2018; Accepted 26 September 2018

\begin{abstract}
This paper, which is not a research paper, elaborates on the innovations made in English linguistics undergraduate courses at the University of Languages and International Studies - Vietnam National University, Hanoi (ULIS) during the last ten years, from 2009 to 2018. The report on the changes in teaching and learning English linguistics was informed from the 4 published research papers, the contents of which functioned as jigsaw pieces together combining and complementing to make up the complete picture of teaching and learning English linguistics at ULIS over the last decade. The report was also informed from the observation of how English linguistics has been taught and learnt over the last ten years by the author in the roles of a teacher of English linguistics and a course developer at ULIS as well. The comparison between the scenarios of English linguistics teaching and learning before and after 2014 was made, from which the outstanding innovations in teaching and learning English linguistics over the last decade could be seen.
\end{abstract}

Keywords: English linguistics, innovation, thinking skills

\section{Introduction}

English linguistics has been taught to English majors at ULIS as compulsory subjects since the English Linguistics Program and the English Teacher Education Program were established about half a century ago. Since then, to align with the innovations in Vietnam's education system and the drive towards higher quality teaching

* Tel.: 84-989669422

Email: tamntm1982@vnu.edu.vn and learning at ULIS, besides the increase in number of courses, the contents of the English linguistics courses have also been changed. From 5 English linguistics courses including phonetics and English phonology, English grammar, and English Semantics, Pragmatics, and Discourse Analysis being taught in 2009, the number linguistics courses at ULIS was more than doubled by 2015 . The linguistics subjects currently being taught include: Introduction to Linguistics 1 (an brief introduction to Phonetics and 
English phonology, Morphology, Syntax and Semantics), Introduction to Linguistics 2 (a brief introduction to Pragmatics, Sociolinguistics, Discourse analysis, Critical Discourse Analysis, and language acquisition), English Phonology, English Syntax, English Semantics, Pragmatics, Discourse Analysis, Functional Grammar, Research Methods in Applied Linguistics, Sociolinguistics, Text Editing, Sociolinguistics, and World Englishes. The linguistics contents of the courses were updated, and the expected learning outcome were set to be higher, the teaching methodology and students' learning are changing, too. Such changes have been progressively made over the last decade to meet the demand of the international integration process in education, in which benchmarking with similar international programs is a prerequisite to evidence the quality of the tertiary education programs.

\section{Innovation in teaching and learning}

Innovation is often said to be a major driver for maintaining competitiveness in a more and more globalised world. Innovation could be defined as:

' $\ldots$ an idea, practice, or object that is perceived as new by an individual or other unit of adoption...[and] It matters little [...] whether or not an idea is "objectively" new as measured by the lapse of time since its first use or discovery. The perceived newness of the idea for the individual determines his or her reaction to it. If the idea seems new to the individual, it is an innovation' (Rogers, 2003, p. 12)

Besides the definition above, there are other definitions that might vary depending on the specific area of application, as innovation is a very broad concept and could be seen in any fields. However, the definitions share the idea that innovation is a general representation for something new and excellent, which means that innovation could be a crucial factor in society development and welfare gains (OECD, 2016).

In education, innovation could be an informed evidence-based change in philosophy of teaching and learning, which leads to adaptation of instructional practices that better promote educational objectives (De Lano, Riley, \& Crookes, 1994, p. 489)

As stated by UNICEF, innovation in education does not just mean new technology applied to teaching and learning, but a kind of intervention that could (i) improve learning, equity and systems; (ii) solve a real problem in a simple and clear way (be demand-driven); and (iii) match the scale of the problem it is trying to solve. Educational innovation can be found in processes, services, programs and partnerships ${ }^{1}$.

Innovations in curriculum development and teaching methodology started at ULIS in academic year 2011-2012 with a focus on the job-oriented learning outcomes, which are professional knowledge and skills that students will need to prepare for their future jobs. To meet the social demand for high quality human resource in such an era of international integration, the exit requirements of the programs were revised to cover a variety of practical professional skills and wider understanding in different disciplines. Accordingly, English linguistics courses at ULIS have been innovated. The new subjects such as Research Methods in Applied Linguistics or World Englishes were then gradually added to the course list, with the aim to facilitate students with better skills in learning and research and to broaden their view to wider and up-to-date trends in the disciplines, and preparing them better for their future jobs. As one important

https://www.unicef.org/education/ 
learning outcome is students' ability to use critical thinking skills in a creative way to solve problems that they will meet in their future jobs, students' thinking skills development received more attention from course developing teachers. The learning outcomes set in each course were therefore, revised to focus on thinking skills of high levels. As the course objectives were revised, the assessment tools used in the innovated subjects should therefore be reconstructed to accurately measure the extent to which students achieve these course objectives. The teaching methodology were also changed so as to facilitate students' learning better and to smooth their progress along the way towards achieving the exit requirements.

During academic year 2017-2018, the institutional project of examining the alignment between the expected learning outcomes stated and the teaching and learning activities and assessments employed in ULIS courses, hereby called ULIS OTA alignment examination project, was conducted with the involvement of all course developing teachers at ULIS. During six months from October 2017 to March 2018, these ULIS teachers were guided through the process of reflecting on their own teaching practice, and scanning the syllabi and specifications of assessment types to evaluate the alignment between expected learning outcomes, teaching and learning activities and assessments in ULIS courses. The different stages of ULIS OTA alignment examination project were efforts to locate all the problematic issues that might exist in the program curriculum and educational processes, from which the basis for planning future innovations towards higher education quality could be established.

\section{Teaching and learning English linguistics at ULIS from 2009 to 2014 and after 2014}

\subsection{Sources of data}

In this paper, in order to draw a picture of teaching and learning English linguistics at ULIS over the last 10 years, I based myself on three major sources of information: (i) the two papers by Nguyen, Nguyen, Nguyen, and Doan (2015) and Nguyen, Nguyen, Nguyen, and Doan (2016) which report on empirical studies conducted in late 2014, early 2015; (ii) two papers by Nguyen and Nguyen (2017) and Nguyen (2018) which report on innovative action research projects conducted from 2015 to 2017 by teachers of English linguistics of ULIS; and (iii) my own observation as a teacher of English linguistics and a developer of English linguistics courses at ULIS since 2009. Although the scope and aims of the four studies are not quite similar, they all share the aim of investigating how English linguistics was taught and learnt at ULIS.

Source 1: In Nguyen et al. (2015), which focused on the expected learning outcomes of the courses and teaching and learning activities used in ULIS English linguistic classes, and Nguyen et al. (2016), which focused on assessment tools, an overview of how linguistics courses were taught and learnt from 2009 to 2014 was sketched. The data of the two studies were collected from syllabi analysis, test specifications analysis, paper-based questionnaires with students and English linguistics teachers, and interviews with students about the how the learning activities and assessments were conducted in class. The data were then analyzed to see what the expected learning outcomes were set, how the learning activities facilitated students to achieve the expected learning outcomes, and how the learning outcomes could be assessed. 
The analysis was based on a thinking-based frameworkdeveloped in accordance with
Marzano's thinking skills taxonomy as presented in Table 1.

Table 1. The analytical framework developed in accordance with Marzano's thinking skills taxonomy

\begin{tabular}{|c|c|c|c|}
\hline No & $\begin{array}{c}\text { THINKING SKILLS THAT COULD } \\
\text { BE REQUIRED IN LINGUISTIC } \\
\text { TASKS }\end{array}$ & EXAMPLES OF LINGUISTIC TASKS & $\begin{array}{l}\text { MARZANO'S } \\
\text { TAXONOMY }\end{array}$ \\
\hline 4.4 & $\begin{array}{l}\text { Adapt the existing rules/framework to } \\
\text { investigate the linguistic data }\end{array}$ & $\begin{array}{l}\text { Suggest the strategy to translate English } \\
\text { modal devices into Vietnamese }\end{array}$ & \multirow{4}{*}{$\begin{array}{l}\text { UTILIZATION } \\
\text { LEVEL } 4\end{array}$} \\
\hline 4.3 & $\begin{array}{l}\text { Experiment or test the rules/processes in } \\
\text { students' own learning }\end{array}$ & $\begin{array}{l}\text { Speak the sentence in Singaporean English } \\
\text { accent / using the Falling Tune / the Dive. }\end{array}$ & \\
\hline 4.2 & $\begin{array}{l}\text { Figure out a way to solve the existing of } \\
\text { predicted problem }\end{array}$ & $\begin{array}{l}\text { How can the given Facebook statuses be } \\
\text { devoid of sexism? }\end{array}$ & \\
\hline 4.1 & Decide the best among the alternatives & $\begin{array}{l}\text { Which is the most suitable pragmatic } \\
\text { strategy to be used in the situation? }\end{array}$ & \\
\hline 3.4 & $\begin{array}{c}\text { Specify (to defend or judge) the } \\
\text { arguments/viewpoints on a certain issues }\end{array}$ & $\begin{array}{c}\text { Explain how metaphors work in the chosen } \\
\text { text. }\end{array}$ & \multirow{4}{*}{$\begin{array}{l}\text { ANALYSIS } \\
\text { LEVEL } 3\end{array}$} \\
\hline 3.3 & $\begin{array}{l}\text { Form conclusions from the findings about } \\
\text { linguistic data }\end{array}$ & $\begin{array}{l}\text { What type of genre is being used in the text } \\
\text { chosen? }\end{array}$ & \\
\hline 3.2 & $\begin{array}{l}\text { Generalize in terms of broader linguistic } \\
\text { categories/ principles/ visuals }\end{array}$ & $\begin{array}{c}\text { What are the communicative strategies that } \\
\text { speaker A uses in the conversation? }\end{array}$ & \\
\hline 3.1 & $\begin{array}{l}\text { Classify, compare and contrast the issues / } \\
\text { different views on the issues }\end{array}$ & $\begin{array}{c}\text { Classify the cohesive devices used in the } \\
\text { texts. }\end{array}$ & \\
\hline 2.4 & $\begin{array}{l}\text { Represent the language chunks using the } \\
\text { given models }\end{array}$ & $\begin{array}{l}\text { Analyze the constituents of the clause: } \\
\text { He asked me to open the door for him. }\end{array}$ & \multirow{4}{*}{$\begin{array}{l}\text { COMPREHEN- } \\
\text { SION } \\
\text { LEVEL } 2\end{array}$} \\
\hline 2.3 & $\begin{array}{l}\text { Illustrate the linguistic concepts(s)/ } \\
\text { phenomena }\end{array}$ & $\begin{array}{l}\text { Make } 2 \text { clauses in SOV pattern and } 2 \\
\text { clauses in SVOC pattern. }\end{array}$ & \\
\hline 2.2 & $\begin{array}{c}\text { Describe the relationship between the } \\
\text { language chunks }\end{array}$ & $\begin{array}{l}\text { Describe the structure of this noun phrase. } \\
\text { The beautiful lady in pink over there. }\end{array}$ & \\
\hline 2.1 & $\begin{array}{c}\text { Describe the key part of the language } \\
\text { chunks }\end{array}$ & $\begin{array}{l}\text { Transcribe the following words in IPA. } \\
\text { watch, statue, strategic }\end{array}$ & \\
\hline 1.4 & $\begin{array}{l}\text { Identify the different types of certain } \\
\text { linguistic notions or phenomenon }\end{array}$ & $\begin{array}{l}\text { State the morphological processes in the } \\
\text { word: interpersonal }\end{array}$ & \multirow{4}{*}{$\begin{array}{l}\text { RETRIEVAL } \\
\text { LEVEL } 1\end{array}$} \\
\hline 1.3 & $\begin{array}{l}\text { Determine if the statements are true or } \\
\text { false }\end{array}$ & $\begin{array}{l}\text { Decide whether the statement is } \mathrm{T} \text { or } \mathrm{F} \text { : } \\
\qquad / \mathrm{m} / \text { and } / \mathrm{b} / \text { are bilabial sounds. }\end{array}$ & \\
\hline 1.2 & $\begin{array}{l}\text { List the types or name the concept(s)/ } \\
\text { issue(s) being described }\end{array}$ & What are the 3 characteristics of antonyms? & \\
\hline 1.1 & $\begin{array}{c}\text { Recognize a concept from a list of } \\
\text { descriptions }\end{array}$ & $\begin{array}{l}\text { Circle the definition of conceptual meaning: } \\
\text { a. What the word refers to. } \\
\text { b. The dictionary definition of the word. } \\
\text { c. The grammatical category of the word. } \\
\text { d. The speaker's evaluation on using the word. }\end{array}$ & \\
\hline
\end{tabular}

Source 2: From Nguyen and Nguyen (2017), which highlighted the effects of an innovative intervention of integrating explicit higher-order thinking skills instruction in English linguistics classes at ULIS, and from Nguyen (2018), which presented the results of an action research project where the researcher, also a ULIS teacher of English linguistics tried out a new approach in teaching in her own linguistic class, some main ideas of how linguistics courses were taught and learnt from academic year 2014-2015 upto academic 
year 2016-2017 could be generalized. The data of these two studies were collected from assignment analysis, class observation and online questionnaires and interviews with students about the how the learning activities facilitated and assessments required students in their learning. The data in this study were analyzed using the same thinking-based framework in Table 1.

Source 3: As a ULIS teacher of English linguistics and a developer of ULIS English linguistic courses during the period of 20092018, I have always been well-informed of the changes in the number of courses, the course design process, the assessment tools used in linguistics courses at ULIS, which are all publicized in the program specification, teaching schedule and assessment schedule. The information of these kinds is used as complementary source to provide the needed information which is out of the scopes of the four studies mentioned. I also take the data related to English linguistic courses from the data bank of ULIS OTA alignment examination project as a reliable reference in sketching an overview of how English linguistics are currently taught and learnt at ULIS. The data in this project data bank were analyzed using Bloom's revised taxonomy. However, to make the comparison between teaching and learning English linguistics at ULIS from 2009 to 2014 and after 2014 possible, data about learning outcomes and assessment tasks in linguistic courses taken from the data bank of ULIS OTA alignment examination project were re-analyzed using the same analytical framework presented in Table 1 as well.

\subsection{Methodology}

In order to spot out the changes in teaching and learning English linguistics at ULIS from 2009 to 2014 and after 2014, the findings related to teaching English linguistics before 2014 of the studies in source 1 and the findings related to teaching English linguistics after 2014 of the studies from source 2, with the complementation of source 3 were compared. The interpretation and discussion of the changes were in accordance with three big themes: expected learning outcomes, assessments of the learning outcomes, and teaching methodology and student's learning.

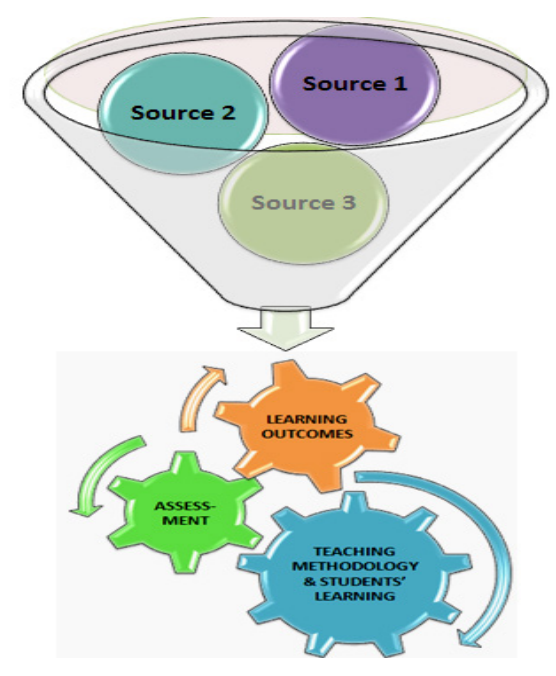

Figure 1. How changes could be identified 
The findings about the differences between teaching and learning from 2009 to 2014 and after 2014 were then discussed to figure out the innovations made in teaching and learning English linguistics at ULIS over the period of 2009-2018.

\subsection{Findings and discussion}

\subsubsection{Teaching and learning English} Linguistics at ULIS from 2009 to 2014

As detailed in Nguyen et al (2015), the analysis of the 5 syllabi used before 2014 revealed that the expected learning outcomes were not clearly stated but could be inferred from the assessment description that the expected learning outcome were set at quite low levels of thinking skills, focusing on the skills at retrieval and comprehension levels. The action verbs used in 4 out of 5 syllabi were mostly to understand or to demonstrate general understanding of what students were taught. In the syllabus of the English Semantics course, the learning outcome was set to a higher level in which the students were expected to carry small research in Semantics; however, the assessment description, no research requirement could be traced. The expected learning outcome of applying what they have learnt in their own study was also mentioned in the course objectives in 2 other syllabi, but not in the assessment description. From my own observation as the teacher of the English linguistics subjects, the applying process was expected to be in students' self-study, which means this was not a compulsory requirement; no assessments were set to measure whether this expected learning outcome is achieved.

Tests prevailed as the dominant assessment type in all courses, especially as end-term assessment. The test specifications analysis and the questionnaire data demonstrated that students were assessed with the tasks requiring them to perform at quite low-level thinking skills of Retrieval and Comprehension in Marzano's taxonomy. The most popular types of assessments were tests (mid-term and endterm), to do which students had to remember the exact definitions of linguistic concepts like morpheme, tense, or basic noun phrase, to understand such linguistic phenomena as homonymy and polysemy so as to identify or distinguish them, or to conduct simple analysis using existing models (eg. to analyze the clause elements). Such findings resonated the finding from syllabi analysis that there seemed to be a small mismatch between the expected learning outcomes and the assessments in 3 out of 5 courses (the outcomes were stated higher than how the students were actually assessed).

As mentioned Nguyen et al. (2016), the interview with 19 students confirmed the absence of compulsory requirement of research and application learning tasks, and informed that the common types of learning tasks required students to remember, understand, or do simple analysis of the English texts. The common teaching methodology was purely lecturebased, i.e. the lecture started with teachers' presentation of the new knowledge and then teachers' exemplification of the concepts or issues presented. Many teachers still "follow the familiar path of passing on the fragmented bits of information that students memorize, but still forget" (Newman 1990:41). Apart from this, the linguistics classes, were usually teachercentered, where the teachers planned and led all the learning activities and assignment in class, provide the keys to the exercises, and their students rarely raised questions on why they needed to learn what they were being taught and if there were any alternative ways to teach and learn more effectively.

The summary of how students were required to learn and be assessed is seen in Table 2. 
Table 2. How students were required to learn and be assessed from 2009 to 2014

\begin{tabular}{|c|c|c|}
\hline No & $\begin{array}{c}\text { HOW STUDENTS WERE POSSIBLY REQUIRED TO LEARN AND } \\
\text { BE ASSESSED }\end{array}$ & $\begin{array}{c}\text { PERCENTAGE } \\
\text { OF COURSES }\end{array}$ \\
\hline $\mathbf{4 . 4}$ & Adapt the existing rules/framework to investigate the linguistic data & $0 \%$ \\
\hline $\mathbf{4 . 3}$ & Experiment or test the rules/processes in students' own learning & $0 \%$ \\
\hline $\mathbf{4 . 2}$ & Figure out a way to solve the existing or predicted problem & $0 \%$ \\
\hline $\mathbf{4 . 1}$ & Decide the best among the alternatives & $0 \%$ \\
\hline $\mathbf{3 . 4}$ & Specify (to defend or judge) the arguments/viewpoints on a certain issues & $0 \%$ \\
\hline $\mathbf{3 . 3}$ & Form conclusions from the findings about linguistic data & $0 \%$ \\
\hline $\mathbf{3 . 2}$ & Generalize in terms of broader linguistic categories/ principles/ visuals & $0 \%$ \\
\hline $\mathbf{3 . 1}$ & Classify, compare and contrast the issues / different views on the issues & $20 \%$ \\
\hline $\mathbf{2 . 4}$ & Represent the language chunks using the given models & $100 \%$ \\
\hline $\mathbf{2 . 3}$ & Illustrate the linguistic concepts(s) / phenomena & $100 \%$ \\
\hline $\mathbf{2 . 2}$ & Describe the relationship between the language chunks & $100 \%$ \\
\hline $\mathbf{2 . 1}$ & Describe the key part of the language chunks & $100 \%$ \\
\hline $\mathbf{1 . 4}$ & Identify the different types of certain linguistic notions or phenomenon & $100 \%$ \\
\hline $\mathbf{1 . 3}$ & Determine if the statements are true or false & $100 \%$ \\
\hline $\mathbf{1 . 2}$ & List the types or name the concept(s)/ issue(s) being described & $100 \%$ \\
\hline $\mathbf{1 . 1}$ & Recognize a concept from a list of descriptions & $100 \%$ \\
\hline
\end{tabular}

In short, before 2014, the expected learning outcomes were not set high enough to necessitate students'critical thinking and creativityinlearning. Students were expected just to understand linguistic issues and do simple linguistic analyses. There seemed to be a misalignment between the expected learning outcomes and the assessments, and tests were overused as the dominant assessment type in English linguistics courses. The teaching methodology was still very much teacher-centered, and students' learning style was generally passive.

\subsubsection{Teaching and learning English} linguistics at ULIS after 2014

During the revision of the ULIS English linguistic courses which started from 2012 and almost finished in 2015, all of the courses in English programs were revised in backward design approach, so there was a systematic uniform among the course syllabi. The course contents have been changed to cover emerging issues in the disciplines with updated references. As regards the process of course revision and development, the expected learning outcomes were clearly set out with the use of action verbs first, the appropriate assessment formats to measure the learning outcomes were then decided, then come the teaching methodology and contents that aid students' learning towards achieving the learning outcomes.

As mentioned, in academic year 2017-2018, the six-month ULIS OTA alignment examination project was conducted at institutional scale to evaluate the degree of alignment between expected learning outcomes and teaching and learning activities and assessments of ULIS courses, so that changes could then be planned. The results 
from examining the expected learning outcomes, teaching and learning activities, and assessments of 12 English linguistics courses depict a optimistic scenario of students' being required to learn and being assessed in these courses. The changes in terms of expected learning outcomes and assessments as revealed from the results of ULIS OTA alignment examination project could be summarized as below:

(i) The expected learning outcomes as stated in the 2018 syllabi are apparently higher than those set before 2014, which means students are now required to use higher order thinking skills to dig deeper in learning tasks. In six out of twelve courses, the learning outcomes reach level 4 - Utilization in Marzano's taxonomy, which means students are expected to learn at a high degree of independence and creativity. However, in three out of twelve English linguistics courses, the course developing teachers still confine the learning outcome almost to Retrieval and Comprehension levels, with a modest extension to the simplest skill in Analysis level.

(ii) The assessment papers are varied in types, including tests, small quizzes, presentation, reflective writing, problem-based tasks, practical language analysis projects, research essay. Many of the assessment types necessitated students' employment of thinking skills of high levels like generalizing, specifying, evaluating, and decision making. All but one learning outcomes as stated were measured in at least one assessment paper.

Table 3 demonstrates the differences in how students were required to learn and be assessed in English linguistics courses before 2014 and how they are currently required to learn and be assessed in these courses.

Table 3. How students are required to learn and be assessed before 2014 and after 2014

\begin{tabular}{|c|c|c|c|}
\hline No & $\begin{array}{l}\text { HOW STUDENTS ARE POSSIBLY } \\
\text { REQUIRED TO LEARN AND BE ASSESSED }\end{array}$ & $\begin{array}{c}\text { PERCENTAGE OF } \\
\text { COURSES 2009- } \\
2014\end{array}$ & $\begin{array}{c}\text { PERCENTAGE OF } \\
\text { COURSES 2014- } \\
2018\end{array}$ \\
\hline 4.4 & $\begin{array}{c}\text { Adapt the existing rules/framework to investigate } \\
\text { the linguistic data }\end{array}$ & $0 \%$ & $0 \%$ \\
\hline 4.3 & $\begin{array}{c}\text { Experiment or test the rules/processes in students' } \\
\text { own learning }\end{array}$ & $0 \%$ & $0 \%$ \\
\hline 4.2 & $\begin{array}{l}\text { Figure out a way to solve the existing or } \\
\text { predicted problem }\end{array}$ & $0 \%$ & $33.33 \%$ \\
\hline 4.1 & Decide the best among the alternatives & $0 \%$ & $50 \%$ \\
\hline 3.4 & $\begin{array}{l}\text { Specify (to defend or judge) the arguments/ } \\
\text { viewpoints on a certain issues }\end{array}$ & $0 \%$ & $58.33 \%$ \\
\hline 3.3 & $\begin{array}{c}\text { Form conclusions from the findings about } \\
\text { linguistic data }\end{array}$ & $0 \%$ & $66.67 \%$ \\
\hline 3.2 & $\begin{array}{l}\text { Generalize in terms of broader linguistic } \\
\text { categories/ principles/ visuals }\end{array}$ & $0 \%$ & $75 \%$ \\
\hline 3.1 & $\begin{array}{c}\text { Classify, compare and contrast the issues / } \\
\text { different views on the issues }\end{array}$ & $20 \%$ & $100 \%$ \\
\hline 2.4 & $\begin{array}{l}\text { Represent the language chunks using the given } \\
\text { models }\end{array}$ & $100 \%$ & $100 \%$ \\
\hline 2.3 & Illustrate the linguistic concepts(s) / phenomena & $100 \%$ & $100 \%$ \\
\hline
\end{tabular}




\begin{tabular}{|c|c|c|c|}
\hline $\mathbf{2 . 2}$ & $\begin{array}{c}\text { Describe the relationship between the language } \\
\text { chunks }\end{array}$ & $100 \%$ & $100 \%$ \\
\hline $\mathbf{2 . 1}$ & Describe the key part of the language chunks & $100 \%$ & $100 \%$ \\
\hline $\mathbf{1 . 4}$ & $\begin{array}{c}\text { Identify the different types of certain linguistic } \\
\text { notions or phenomenon }\end{array}$ & $100 \%$ & $100 \%$ \\
\hline $\mathbf{1 . 3}$ & Determine if the statements are true or false & $100 \%$ & $100 \%$ \\
\hline $\mathbf{1 . 2}$ & $\begin{array}{c}\text { List the types or name the concept(s)/ issue(s) } \\
\text { being described }\end{array}$ & $100 \%$ & $100 \%$ \\
\hline $\mathbf{1 . 1}$ & Recognize a concept from a list of descriptions & $100 \%$ & $100 \%$ \\
\hline
\end{tabular}

In terms of changes in teaching methodology and students' learning, the empirical research reported in Nguyen and Nguyen (2017) and Nguyen (2018) could inform about some innovative changes.

In Nguyen and Nguyen (2017), an intervention was made in 2 classes of Introduction to English Linguistics 2 (one in academic year 2015-2016 and the other in academic year 2016-2017): providing explicit instructions on using higher-order thinking skills in learning activities explicitly instructing students how to learn, and providing explicit instructions on using higher-order thinking skills in assessments explicit instructing students how to perform at their best as well. The intervention was made in two cycles, with the hypothesis that explicit instructions on using higher-order thinking skills in learning activities and assessments was appropriate to promote students' learning and motivation. From the data collected from class observation, assignment analysis, and a group interview with students, it was concluded that the intervention of making thinking skills requirements explicit to students in learning task instructions and assessment instructions was a good choice for teaching Introduction to English Linguistics courses. The students in the class with intervention gradually learnt how to shape their effective learning process, performed better in learning activities and assessments than students in the no-action class, and they became more creative and more motivated in learning. The intervention therefore has now been disseminated to some other classes of Introduction to English Linguistics 2 and other linguistics courses of Discourse Analysis, Functional Grammar, and World Englishes as well. The assessment instruction developed during the research project of Nguyen and Nguyen (2017) has now become the official version for final assignment in Introduction to English Linguistics 2 courses.

In Nguyen (2018), problem-based learning - a modern learner-centered approach, was applied in a two-cycle action research project in two undergraduate Semantics classes (one in academic year 2015-2016 and the other in academic year 2016-2017). With the assumption that problem-based learning could promote students' thinking skills and facilitate their learning, the learning and formative assessment tasks were designed to be problem-based, where students have to make use of the knowledge they had learnt and thinking skills of high levels to solve authentic problems; goal-oriented learning occurred during this process of problem solving. The data collected from class observation, online questionnaire, focused-group interview, and assignment analysis all led to the conclusions that problem-based tasks could effectively facilitate students' learning of linguistics as well as other content subjects; students became 
more active and motivated when learning in such a learner-centered approach. The findings of this research project were disseminated and the problem-based approach has been extended to Text Editing and Functional Grammar (undergraduate level) courses and to Semantics course at graduate levels as well.

As a teacher in English Linguistic Division, I could recently hear of project-based learning and teaching activities conducted in ULIS English linguistic classes. However, the innovative attempts are still in progress and no research-based results of these activities have been reported in any published work.

To sum up, in comparison to what happened before 2014, the teaching and learning of English linguistics after 2014, as reflected from results of ULIS OTA alignment examination project as well as in Nguyen and Nguyen (2017) and Nguyen (2018) evidence many changes. In terms of expected learning outcomes, by 2018, the expected learning outcomes are stated explicitly with the use of action verbs in all syllabi of English linguistics courses; the learning outcomes were prevalently set to be at high levels of Analyzing and even Utilization in Marzano's taxonomy (before 2014, the learning outcomes were confined mostly to Retrieval and Comprehensions - the two low levels in Marzano's taxonomy). In terms of assessments, the assessment papers are no longer simply tests, but many other types of assessment (problem-based tasks, practical projects, research essay) have been designed to call for students' employment of critical thinking and creativity. The learning outcomes and the assessments in English linguistics courses were almost perfectly matched. In terms of teaching methodology, researchbased attempts to promote students learning and motivation were tried out, reflected, and disseminated. Innovative project-based teaching and learning activities could be observed in some classes, but no researchbased results have been publicized yet.

\section{Conclusions}

Besides the observable increase in the number of courses, when combining and comparing the three sources of data, the following innovations in teaching and learning English linguistics at ULIS could be identified:

In terms of expected learning outcomes of the courses, there has been a noticeable leap from outcomes categorized to be of low levels of Retrieval and Comprehension to outcomes categorized to be of high levels of Analysis and Utilization in Marzano's thinking skills taxonomy in almost every course. In other words, there seems to be a change in teachers' expectation about students moving from surface learning towards deep learning.

In terms of assessments, there is a remarkable enhancement in the alignment between assessments and expected learning outcomes in the English linguistics courses. If by 2014 , the mismatch between what was set out for students to achieve and what could be measured about their achievement could be found in $60 \%$ of the courses, by March 2018, the alignment between assessments and expected learning outcomes set for all the twelve English linguistics courses was nearly perfect. From the one and only dominant type of tests prevailing as both mid-term assessment and end-term assessment in all courses, by 2018, assessment types has been significantly diversified to include criticalthinking-necessitated types like problembased tasks, research essays, projects.

In terms of teaching methodology, from the traditional lectured-based and teacher-centered models easily found in any ULIS linguistic classes before 2014, innovations have been made by teachers in different courses in the form of action 
research projects. The innovative interventions might be simple and practical as providing explicit instruction on how students should use thinking skills in their learning and assessments, or a bit more complex as designing the learning and formative assessment tasks in the form of ill-structured problems, so that students could be submerged in goal-oriented creative learning in motivating learner-center classroom context. At least two action research projects have been conducted, reflected, and findings publicized for dissemination. Other efforts to innovate teaching methodology related to project-based learning could also be heard of. The observable trend in innovating teaching methodology seems to be a change from being highly teacher-centered to more and more student-centered.

In terms of students' learning, in accordance with attempts to innovate in teaching methodology, changes could be seen in students learning. From passive-learning students who spent most of their efforts in rote learning and who almost never voice up any questions, many students have been able to shape their effective learning process, learn more actively with good motivation in learning.

Despite all the innovations as described, there still exist problems as pointed out in 3.3.2. In the near future, all the problems as identified in the ULIS OTA alignment examination project would soon be solved as planned. The contents in the English linguistics courses at ULIS would be updated to cover the up-to-date issues and trends in the linguistic discipline. The research-based innovations in teaching and learning English linguistics at ULIS as presented would be disseminated on a larger scale.

\section{References}

De Lano, L., Riley, L., \& Crookes, G. (1994). The meaning of innovation for ESL teachers. System, 22, 487-496. http://dx.doi.org/10.1016/0346251X(94)90005-1.

Marzano, R. J., \& Kendall, J. S. (2007). The new taxonomy of educational objectives (2nd Ed.). Thousand Oaks, CA: Corwin press.

Newman, M. F. (1990). Higher order thinking in teaching social studies: A rationale for the assessment of classroom thoughtfulness. Journal of Curriculum Studies, 22(1), 41-56.

Nguyen, T. M. T., Nguyen, H. D., Nguyen, L. T. T., \& Doan, N. T. (2015). Students' employment of highorder thinking skills in English Linguistics Courses: A case study at VNU-ULIS. Proceedings of an ELT conference on innovative English language teaching for provincial universities, 215-220, Quảng Bình: Quảng Bình University Press.

Nguyen, T. M. T., Nguyen, H. D., Nguyen, L. T. T., \& Doan, N. T. (2016). An investigation into how QH2012. F1 students use higher-order thinking skills in English linguistics assessments at VNU-ULIS. VNU Journal of Foreign Studies, 32(3), 57-66.

Nguyen, T.M.T.\& Nguyen, L. T. T. (2017). The influence of explicit higher-order thinking skills instruction on students' learning of linguistics. Thinking Skills and Creativity, 26(2017), 113-127. http://dx.doi. org/10.1016/j.tsc.2017.10.004

Nguyen, T.M.T. (2018). Using problem-based learning to promote students' use of higher-order thinking skills and facilitate their learning. VNU Journal of Foreign Studies, 34(2), 90-110.

OECD Center for Educational Research and Innovation - CERI (2008). Innovation strategy for education and training innovation. Paris: OECD Publishing. Retrieved from http://www.oecd.org/edu/ ceri/40815797.pdf

OECD (2016). Innovating Education and Educating for Innovation: The Power of Digital Technologies and Skills. Paris: OECD Publishing. Retrieved from https://www.oecd-ilibrary.org/education/ innovating-education-and-educating-forinnovation_9789264265097-en

Rogers, E. (2003). Diffusion of Innovations $5^{\text {th }} \mathrm{Ed}$. NewYork: Free Press. 


\title{
DẠY VÀ HỌC NGÔN NGỮ HỌC TIẾNG ANH BẬC ĐẠI HỌC TẠI TRƯỜ'NG ĐẠI HỌC NGOẠI NGŨ' - ĐẠI HỌC QUỐC GIA HÀ NỘI: NHỮNG BIẾN ĐỔI TRONG 10 NĂM QUA
}

\begin{abstract}
Nguyễn Thị Minh Tâm
Khoa Ngôn ngũ và Văn hóa các nước nói tiếng Anh, Trường Đại học Ngoại ngũu, ĐHQGHN,

Phạm Văn Đồng, Cầu Giấy, Hà Nội, Việt Nam

Tóm tắt: Bài viết trình bày về những đổi mới đã diễn ra trong quá trình dạy và học các môn Ngôn ngữ học tiếng Anh tại Trường Đại học Ngoại ngữ - Đại học Quốc gia Hà Nội (ĐHNNĐHQGHN) trong khoảng thời gian 10 năm từ 2009 đến 2018. Thông tin sử dụng trong bài viết này được lấy từ bốn bài nghiên cứu đã công bố trước đó có nội dung liên quan tới việc giảng dạy Ngôn ngữ học tiếng Anh và từ sự quan sát của tác giả với vai trò là một giáo viên giảng dạy Ngôn ngữ học tiếng Anh, đồng thời là người tham gia xây dựng và điều chỉnh nội dung, quá trình triển khai các khóa học Ngôn ngữ học tiếng Anh tại ĐHNN-ĐHQGHN.
\end{abstract}

Tù khóa: ngôn ngữ học tiếng Anh, đổi mới, kỹ năng tư duy 